\title{
Pronethalol in Treatment of Ventricular Arrhythmias During Anaesthesia
}

\author{
J. P. PAYNE,* M.B., CH.B., D.A., F.F.A. R.C.S.; R. M. SENFIELD,* M.D.
}

Brit. med. F., 1964, 1, 603-604

Ventricular extrasystoles often occur during surgery and may be due to a direct effect of the anaesthetic on the heart or, more commonly, to endogenous adrenaline release in response to the stimulus of carbon-dioxide retention. Such irregularities may also develop if adrenaline is used for infiltration during anaesthesia with such drugs as chloroform and cyclopropane. Other reported causes of ventricular irregularities include exposure and handling of the heart, total body-cooling, surgical interference with the sympathetic nervous system such as the mobilization of a phaeochromocytoma, and certain manipulations such as traction on viscera.

Although the risk of disturbances of cardiac rhythm progressing to ventricular fibrillation is difficult to assess, most anaesthetists accept the possibility and would welcome a drug capable of controlling ventricular arrhythmias. In 1962 Black and Stephenson introduced a specific adrenergic $\beta$-receptor antagonist, pronethalol, which blocked the cardiac effects of both catecholamine release and sympathetic stimulation and which had no intrinsic sympathomimetic activity. The present study was undertaken to test the ability of this drug to control cardiac irregularities occurring under anaesthesia.

\section{Method}

The studies were carried out during anaesthesia on patients of both sexes admitted to hospital for a variety of elective surgical procedures. After assessment to exclude major respiratory and cardiac disease the nature of the investigation was explained to each patient and consent obtained.

The patients were prepared for surgery in the usual way: in most instances anaesthesia was established with intravenous thiopentone $250-500 \mathrm{mg}$. or occasionally methohexitone 100 $200 \mathrm{mg}$. When endotracheal intubation was indicated, suxamethonium $30-50 \mathrm{mg}$. was used to facilitate the procedure. Anaesthesia was continued with chloroform, cyclopropane, or halothane, using oxygen as the carrier gas in a closed-circle system with a carbon-dioxide absorber included. Breathing was spontaneous throughout the period of the study. In one patient undergoing laryngeal biopsy, halothane was administered through a semi-closed partial rebreathing system.

In every patient the rate and rhythm of the heart were observed continuously by electrocardiographic monitoring on an oscilloscope attached to an Elema Schönander mingograph type 42.B recorder. A second channel of the recorder was used to monitor the blood-pressure. For this purpose the recorder was connected through a transducer to a polythene catheter inserted percutaneously into the radial artery immediately above the wrist-joint.

Samples of arterial blood were obtained at intervals from the same catheter for the determination of $p \mathrm{H}$, carbon-dioxide tension, and standard bicarbonate by a method based on that of Astrup (1956) using the nomogram described by Siggaard Andersen and Engel (1960). The first blood sample was withdrawn during normal sinus rhythm either while the patient was * Research Department of Anaesthetics, Royal College of Surgeons of
England, and Hammersmith Hospital, London. still conscious or immediately after induction. As soon as ventricular disturbances were observed a second blood sample was obtained, and this was followed by the intravenous injection of 2.5 to $10 \mathrm{mg}$. of pronethalol in a concentration of either 0.01 or $0.1 \%$ over a period of 30 seconds. Normal sinus rhythm usually returned within 90 seconds of the injection, after which a third blood sample was taken.

\section{Results}

Ventricular extrasystoles occurred in 22 patients and in every instance normal rhythm was restored by the intravenous injection of pronethalol (see Fig.).

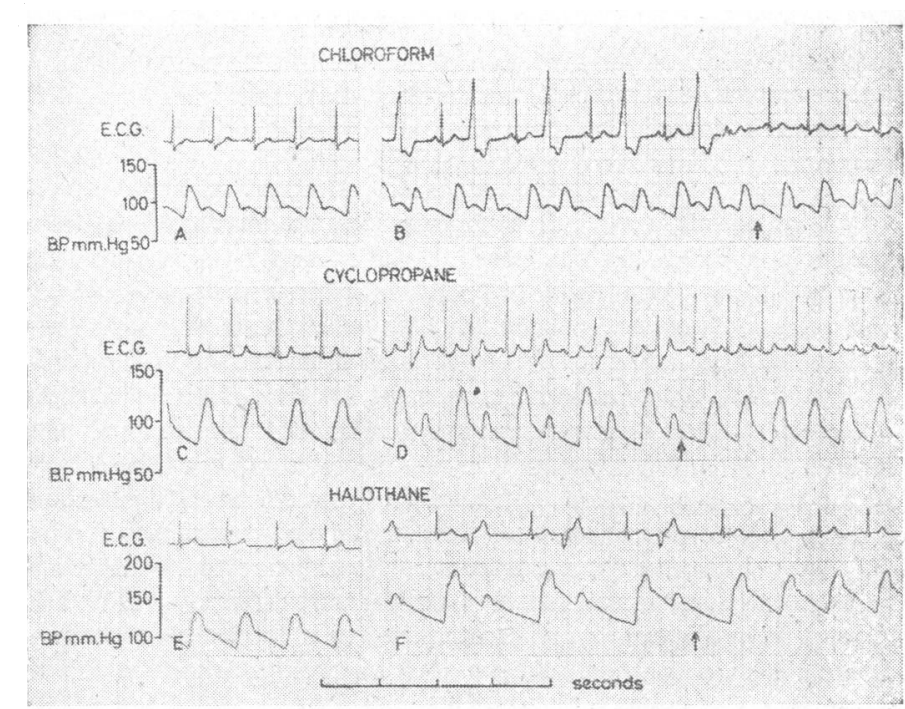

Electrocardiograms (lead II) and blood-pressure tracings showing the effect of pronethalol injection on ventricular arrhythmias. $A, C$, and $E$ are post-induction controls. The arrows in $B, D$, and $F$ indicate the resumption of normal sinus rhythm 58,90 , and 80 seconds respectively after the intravenous injection of pronethalol.

Of the 22 patients studied, 10 were anaesthetized with halothane and in eight of these normal rhythm returned in a mein time of 74.4 seconds (range 22-124) after the start of the injection of $10 \mathrm{mg}$. of pronethalol. In two patients, however. ventricular extrasystoles reappeared, in the first instance two minutes after normal rhythm had been restored and in the second 45 minutes after; a further $10-\mathrm{mg}$. dose of pronethalol abolished the arrhythmias permanently. In one patient-the first to whom the blood was given-an initial injection of 2.5 mg. was ineffectual, but when the dose was repeated the irregularities were abolished within two minutes. In the remaining patient, made apnoeic for laryngeal biopsy, three 10-mg. doses of pronethalol were needed to bring about the return of normal rhythm.

Six of the patients who developed ventricular extrasystoles were anaesthetized with cyclopropane and in all six a 10-mg. dose of pronethalol given intravenously antagonized the arrhythmias in a mean time of 49.7 seconds (range 23-90) from 
the beginning of the injection. In three patients the extrasystoles returned 10 minutes later but were blocked again by the same dose of drug without further recurrence.

The remaining six patients were anaesthetized with chloroform and again the intravenous injection of pronethalol (10 mg.) blocked the arrhythmia in a mean time of 78 seconds (range 39-140) from the start of the injection. Recurrence of irregularities in one patient was abolished by repeating the dose.

The onset of extrasystoles in these 22 patients was associated with a significant increase in heart rate from $84 \pm 25.2$ to 112 $\pm 24.8(\mathrm{P}<0.005)$. The subsequent decrease in heart rate to $95+21.6$ after the injection of pronethalol was also significant $(P<0.025)$. The effect of pronethalol on blood-pressure was much less marked than on the heart rate and rhythm, and indeed no particular pattern was observed in the 16 patients on whom measurements were made.

In 16 patients arterial carbon-dioxide tensions were also measured and in each a definite rise preceded the onset of ventricular extrasystoles; when the arrhythmias appeared the mean value had risen from the control level of 37.5 to $69.3 \mathrm{~mm}$. $\mathrm{Hg}$. The mean arterial $\mathrm{PCO}_{2}$ continued to rise slightly to $74.4 \mathrm{~mm}$. Hg after normal rhythm had been restored by pronethalol.

Associated with the rise in arterial carbon-dioxide tension was a fall in arterial $\mathrm{pH}$ from a mean control value of 7.34 to 7.11 , which was virtually unchanged at 7.10 after the injection of pronethalol. The absence of any significant change in the standard bicarbonate values indicated that the acidosis was primarily respiratory and could be attributed to the rise in $\mathrm{PCO}_{2}$.

\section{Discussion}

The onset of ventricular extrasystoles in our patients was always associated with a raised carbon-dioxide tension in the arterial blood. This relation between ventricular extrasystoles and carbon-dioxide retention during anaesthesia was first described by Johnstone $(1948,1950)$ and later amplified by Price et al. (1958), who showed that a raised carbon-dioxide tension in the blood provoked a sympatho-adrenal response with the release of catecholamines. They suggested that such catecholamine release was greater during cyclopropane anaesthesia than during the administration of halothane, thus explaining why the $\mathrm{PCO}_{2}$ threshold for ventricular arrhythmias was lower with cyclopropane than with halothane (Black et al., 1959). Although in our study the data were insufficient for a comparable statistical analysis, the pattern of behaviour of cyclopropane and halothane was similar to that described by Price et al. (1960). In addition the behaviour of chloroform followed closely that of cyclopropane.

Our results show that such ventricular extrasystoles during anaesthesia can be abolished by the intravenous injection of pronethalol even when the carbon-dioxide tension is still rising. Moreover, the dose for this purpose is only a small fraction of that used safely by Dornhorst and Robinson (1962) and by Pilkington et al. (1962) in their experimental studies on conscious volunteers.
The absence of any significant effect of pronethalol on bloodpressure and the return of the pulse rate to normal when the extrasystoles had disappeared are in agreement with the observation of Dornhorst and Robinson (1962) that in six conscious subjects given pronethalol $(1-1.5 \mathrm{~mm} . / \mathrm{kg}$.) the drug had no consistent effect on the resting pulse rate and blood-pressure.

An additional advantage of pronethalol has been suggested by the studies of Vaughan Williams and Sekiya (1963) on guinea-pigs and of Murray et al. (1963) on dogs. These workers showed that in animals premedicated with pronethalol the threshold for cardiac arrhythmias was significantly raised. If, as our results imply, a similar elevation in threshold occurs in man, then the administration of pronethalol as premedication should guard against the disturbances of rhythm often provoked by infiltration of adrenaline, interference with the sympathetic nervous system, induction of hypothermia, and other similar procedures under anaesthesia.

\section{Summary}

In 22 patients in whom ventricular extrasystoles developed during anaesthesia with chloroform, cyclopropane, or halothane the carbon-dioxide tension was raised.

In all of these patients the intravenous injection of an adrenergic $\beta$-receptor antagonist, pronethalol, abolished the arrhythmia despite the fact that the carbon-dioxide tension was virtually unchanged. In 16 patients a single dose of $10 \mathrm{mg}$. of pronethalol was effective. In five such a dose abolished the arrhythmia temporarily but a second dose was needed to achieve a permanent effect. In the last patient three injections of 10 $\mathrm{mg}$. were required before the extrasystoles were abolished.

In such doses pronethalol abolished the tachycardia induced by carbon-dioxide retention and had no significant effect on blood-pressure.

It was suggested that pronethalol should be used as premedication in patients in whom ventricular extrasystoles were likely to occur during anaesthesia.

We are indebted to our colleagues in the departments of surgery and obstetrics in the Postgraduate Medical School for their co-operation, and to Mr. A. W. Muir and Miss S. D. Scott for technical assistance.

\section{REFERENCES}

Astrup, P. (1956), Scand. 7. clin. Lab. Invest., 8, 33

Black, G. W., Linde, H. W., Dripps, R. D., and Price, H. L. (1959). Brit. F. Anaesth., 31, 238.

Black, J. W., and Stephenson, J. S. (1962). Lancet, 2, 311.

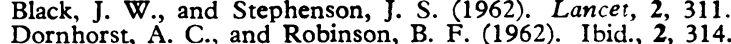

Dornhorst, A. C.. and Robinson, B. F. (1962). Ibid., 2, 314 . Johnstone, M. W. (1948). M.D. The

Murray, W. J., McKnight, R. L., and Davis, D. A. (1963). Proc. Soc exp. Biol.' (N.Y.), 113, 439 .

Pilkington, T. R. E., Lowe, R. D., Robinson, B. F., and Titterington, E (1962). Lancet, 2, 316

Price, H. L., Lurie, A. A., Black, G. W., Sechzer, P. H., Linde, H. W. and Price, M. L. (1960). Ann. Surg., 152, 1071.

Jones, R. E., Price, M. L., and Linde, H. W. (1958). Anesthesiology, 19, 619.

Siggaard Andersen, O., and Engel, K. (1960). Scand. F. clin. Lab. Invest. 12, 177

Vaughan Williams, E. M., and Sekiya, A. (1963). Lancet, 1, 420. 